\title{
21世紀へ持ち込む有機合成の 知的エネルギー源
}

磯 部 稔

Minoru Isobe

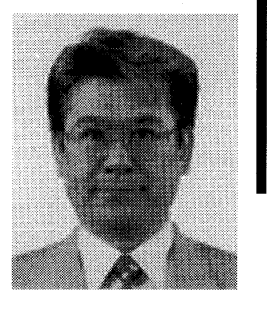

2000 年紀の初年として区切りをつける機会が多い。 自身への反省と次世紀に持ち込む知的エネルギーは何か と思い振り返って見た。

$\mathrm{Q}=$ 目的は? $\mathrm{A}=$ 分子を造るのが有機合成の目標であ る。

$\mathrm{Q}=$ なぜ合成するのか $? \mathrm{~A}=$ =生物分子の仕組みを明らか にするため。

$\mathrm{Q}=$ どのように合成するのか？ $\mathrm{A}=$ 物質を通して生物系 と会話するために, 語彙となる分子・立体化学・官能基 などの自由な合成方法論が欲しい。

設定した目標が達成できた瞬間は最も興奮し感動す る。設定目標が高いと大きな感動はまれにしかないが, 小さな歓びは多い。天然物全合成を完成したとき, 培っ てきた立体化学制御合成方法論が一般性・実用性の拡張 に成功したとき，その瞬間の思いはひとしおである。

コロンビア大学留学後まず課題としたバーノレピン 1 は, キク科植物から得られた抗喉頭癌セスキテルペンで ある。立体電子効果・共役付加反応・シグマトロピー転 位反応などを利用して立体制御全合成を 1977 年に完成 した。ここで学んた $\mathrm{A}$ 張力効果は, その後合成方法論 展開の中で私の感動の化学となっている。MalhotraJohnson (A 張力) 効果によれば, エキソ型オレフィン 2, 3 とで環内のメチル基がアキシアル位の 2 空間配列がエ クアトリアル位の 3 より安定である。バーノレピン合成 の随所でこの効果を利用した。4のエキソオレフィンに ついて, 図のような環状ホウ素中間体を形成し $\mathrm{sp}^{2}$ 面の $\alpha$ 側から選択的にヒドリド還元した。

メイタンシン 5 は，ニシキギ科潅木の成分で強い抗癌 活性アンサマクロリドである。1982 年に全合成を完成 した。5を2 分し不斉炭素原子が多い 8 を鎖状で立体制 御することを考えた。2 と 3 の関係から環を除くと 6 と 7 になり，これを元に $\mathrm{sp}^{2}$ 面を区別する鎖状立体制御法 を考案した。今度は回転する結合を 0ー360 度考慮する が, 鎖状でもメチル基間の反発は 7で最大になり, 安定
コンフォーマーは 6 に近い。これをアサイクリック系ア リル張力 (AAS) とする。不斉炭素の置換基の 1 つを酸 素原子とし電子効果 ・キレーション効果を Felkin 則に 基づいて活用した。結合形成反応に利用するためビニル スルフォン・ビニルシランなどへテロ原子団を導入し た。8はメイタンシンの不斉炭素原子 7 個のうち 4 個を 持つ合成中間体で, $\mathrm{sp}^{2}$ 面を区別してエポキシドを立体 選択的に入れるためのもの。オレフィンとアリル位不斉 炭素原子の回転を制限された相対立体配置系をまず確保 し, 次いで酸素原子側に多酸素のキレーションサイトを つくり, 付加反応が擬似分子内といえるほど速やかに syn 選択的に進行するよう設計した。へテロ共役付加反 応と名づけたオレフィンの面区別的炭素-炭素結合形成 鍵反応で 9 を得た(溶媒の極性や添加物によりキレーショ ンを阻害すると, 電子効果のため主生成物の立体化学は 逆転する)。スルフォニル基は, 次の炭素-炭素結合形成オレフィン形成時の脱離基としても有効に働く。

メイタンシン合成では, ラセミ型では 2 量化アクロレ イン 10 を, 光学活性型ではマンノース 11 をそれぞれの 原料とした。10に存在する唯一の不斉源から 6 個すべ ての不斉中心を誘導した。AASによる8への $\mathrm{sp}^{2}$ 面区 別エポキ化には, ラセミ体の場合には完全に基質(ジア ステレオ)選択的な反応が求められた。面白いことに, Sharpless の不斉エポキシ化反応から不斉源(酒石酸工 ステル)を除くことで解決できた。不斉源存在下では試 薬 (エナンチオ) 選択的な反応が起こり, 速度論的な分割 がみられた。一方, 光学活性体はキラル試薬からの助け のため合成はより易しい。

メイタンシン合成にめどが立った 1981 年暮れに, 米 国アイオワ州立大学の客員教授としてコースを教えた。 次の計画を齐りつつその帰路, ハワイ大学の Scheuer 教授に会ったことがきっかけとなってオカダ酸の合成研 究を始めた。1986 年に完成したオカダ酸 13 の全合成で は, 研究目的の中に次の項目も加えた。へテロ共役付加 

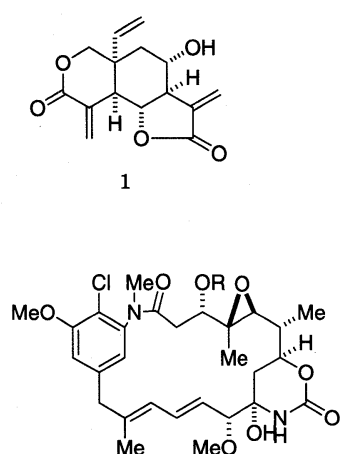

5
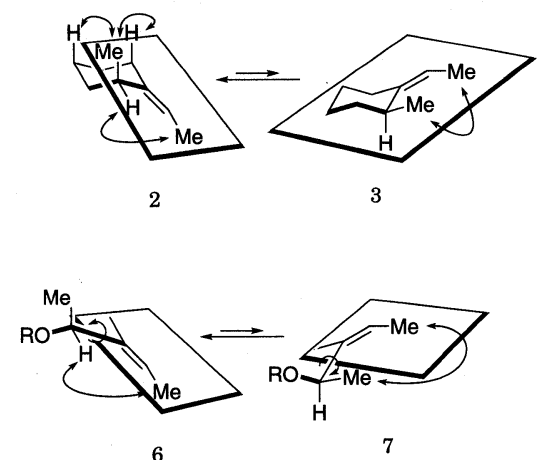

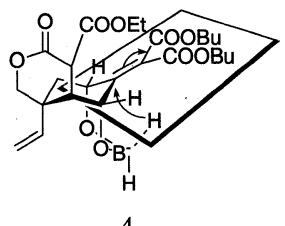

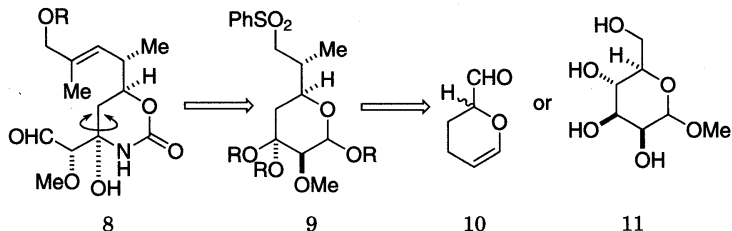

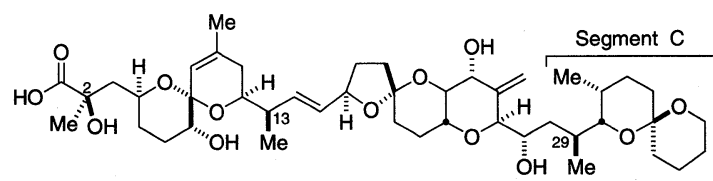

を syn 選択的だけでなくanti 選択的な制御にも切り替 えられる方法論をめざすこと。 $\beta$-キレーション法とし てテトラヒドロピラン環の 12 で $\mathrm{R}=\mathrm{O}^{-}$(アルコキシド) になると付加の方向も切り替わることがわかった。メチ ルリチウムを付加すると，13 位は anti 選択的に 29 位 はsyn 選択的にほぼ完全に制御できた。 5 種の anti 選 択法を確立した。スルフォニル基は，14-15 の Julia 反 応や， 27 のアルデヒドへの付加反応などセグメントカッ プリングに有効に働いた。テトラヒドロピラン環の外 向けて $\mathrm{sp}^{2}$ 面を区別し不斉誘導する手法は, オカダ酸 の 2 位の立体制御にも拡張した。14の 3 置換オレフィ ンでは, AAS はここでも $\mathrm{sp}^{2}$ 面を 2 分し酸素の側・反 対側ということになる。この原理でエポキシ化反応は, 1 位のアセタール型よりもラクトン型の方が立体電子効 果が強く, また, オキシ水銀化反応は水溶液中で立体制 御した。

1986 年夏にオランダ・ナイメーゲン大学の客員教授 として滞在したときコンピューターの ChemX と出会っ た。1990 年バイオグラフその後マクロモデルを用いた 計算機化学が導入され, コンフォマーの安定度が計算で 客観化できるようになった。 $\mathrm{sp}^{2}$ 面と不斉炭素との 2 面 角を 5 度毎に回転・ミニマイズしプロットした（図： 16)。AAS は定量的に評価できるようになった。Aが $99 \%$ のコンフォマーで 15 に相当し, B は $2 \mathrm{kcal} / \mathrm{mol}$ の 差で 17 となり無視できる。反応生成物の異性体比率が
直接原料のコンフォーマーの存在割合に基づくことは, 遷移状態がそれに近く反応速度も速いことが前提になる が実例は多い。

トートマイシン 22 の合成研究開始前, 1992 年ごろ理 研に磯野主任研究員をたずねフォスファターゼ阻害活性 について教えていただいた。トートマイシン合成の中に 活性発現と, 合成方法論展開との二目的で始めた。オカ ダ酸との関連が再課題となるので，へテロ共役付加方法 論の再拡張を行った。合成原料の調製法も根本的に改 め, 糖質 18 にアセチレンを付加し 19 を $\alpha$-ヘテロオレ フィン 20 あるいは 21 とした。この新ルートは $\alpha$-糖ア セチレンをコバルトヘキサカルボニル錯体を用いて $\beta$ 型へのエピ化を含む(この方法論の展開はシガトキシン 合成にも共通する)。これにより D 糖から合成を出発し ても, 両鏡像体を選択的に合成できるエナンチオスウイッ チング法に発展した。

ジアステレオおよびエナンチオスウィチングによる立 体制御は，合成ルートを大きく変更することなく 4 種の 立体異性体が合成可能となる。トートマイシン 22 のセ グメントCは，オカダ酸のセグメントCの部分と似てお り，スピロ部分が鏡像体関係にある。D-グルコースか ら鏡像体変換法を使って実際に23,24 の両鏡像体を合成 し，オカダ酸のセグメント C 新合成を経て，スピロ部分 のフォスファターゼに対する役割を評価するためのハイ ブリド化合物 25,26 を合成した。両者は 1 型 2 型酵素に 


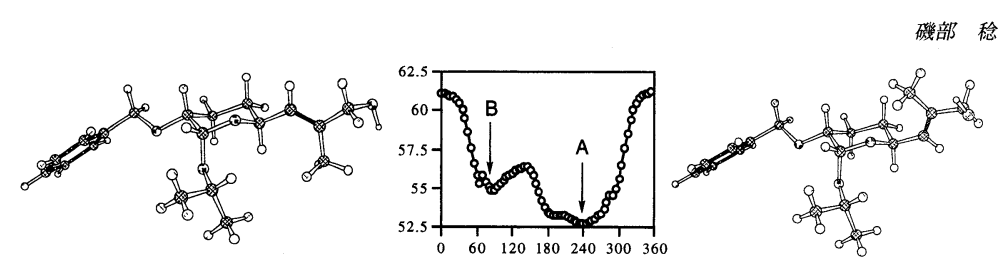

15

16

17

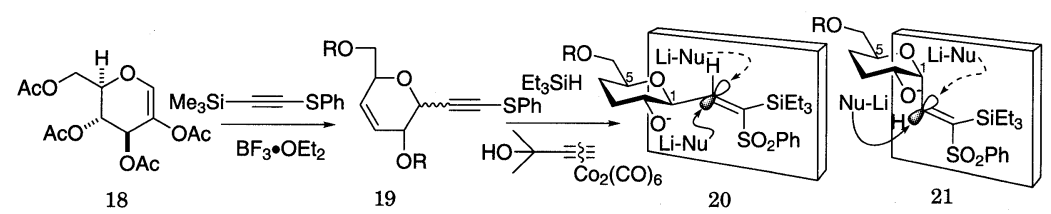

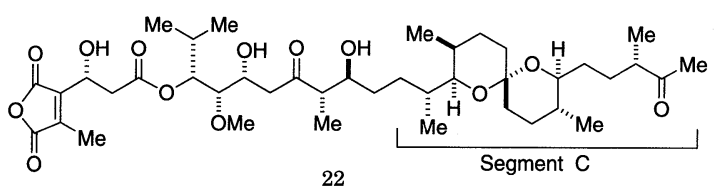
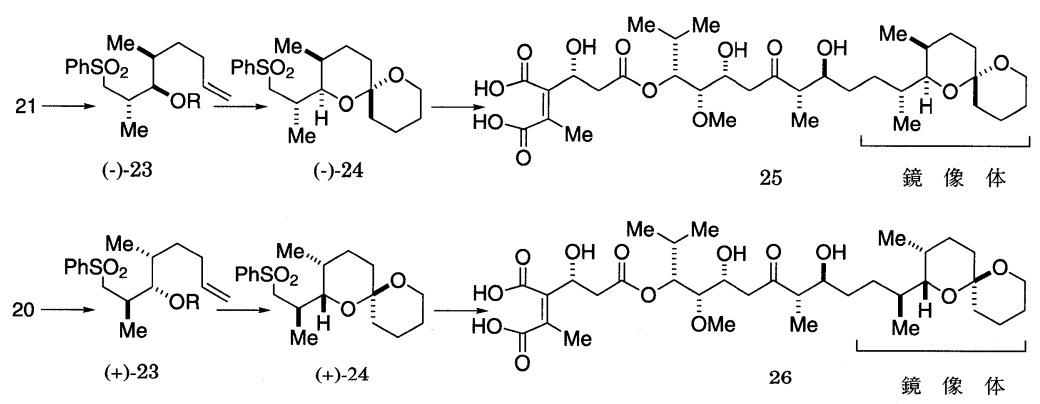

対する特異性が逆転することもわかった。

有機合成の研究の進展にはいろいろな段階がある。合 成反応がうまく行くようになった，選択性が良くなっ た，鍵中間体ができた，全合成ができた，生物機能研究 用の同位体標識化合物ができたなどなど，それぞれの区 切りでわくわくして待った結果に喜び，悲しみ，驚き， さらに次へのエネルギーに振り替えて進んで行く。若い 人達と成功・失敗の結果を共有することが歓びである。 また, 長い研究が物語のように歴史と将来への方向性が 見渡せるようになることは改めて喜ばしいものである。

\section{文 献}

1) (a) M. Isobe, H. Iio, T. Kawai, T. Goto, J. Am. Chem. Soc., 100, 1940 (1978); (b) H. Iio, M. Isobe, T. Kawai, T. Goto, ibid., 101, 6076 (1979)

2) (a) M. Isobe, M. Kitamura, T. Goto, J. Am. Chem. Soc., 104, 4997 (1982); (b) M. Kitamura, M. Isobe, Y. Ichikawa, T. Goto, ibid., 106, 3252 (1984)

3) (a) M. Isobe, Y. Ichikawa, T. Goto, Tetrahedron Lett., 27, 963 (1986); (b) M. Isobe, Y. Ichikawa, D-L. Bai, H.Masaki, T.
Goto, Tetrahedron, 43, 4767 (1987)

4) (a) Y. Ichikawa, K. Tsuboi, Y. Jiang, A. Naganawa, M. Isobe, Tetrahedron Lett., 36 (\#39), 7101 (1995); (b) K. Tsuboi, Y. Ichikawa, Y. Jiang, A. Naganawa, M. Isobe, Tetrahedron, 53, 5123 (1977)

5) M. Isobe, R. Nishizawa, S. Hosokawa, T. Nishikawa, Chem. Commun. (Feature Article), 1998, 2665

(2000 年 1 月 27 日受理) 